\title{
Short-Term Mortality in Adult Patients With Seizures Admitted to the Emergency Department and a Comparison of the First and Recurrent Seizure
}

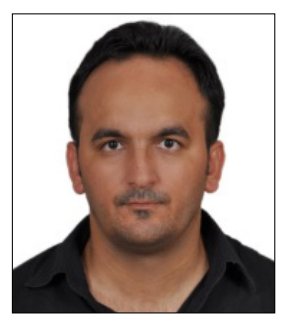

Turgay DEMIR, M.D.

\section{Acil Servise Nöbet Nedeniyle Başvuran Hastalarda Erken Dönem Mortalite ve IIlk Nöbet-Tekrar Nöbetlerin Karşılaştırıma}

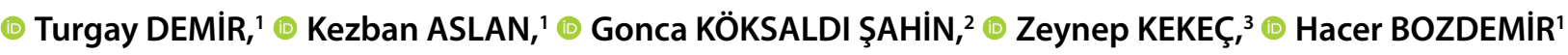 \\ 'Department of Neurology, Çukurova University Faculty of Medicine, Adana, Turkey \\ 2Department of Emergency Medicine, University of Health Sciences, Adana City Hospital, Adana, Turkey \\ ${ }^{3}$ Department of Emergency Medicine, Çukurova University Faculty of Medicine, Adana, Turkey
}

\section{Summary}

\begin{abstract}
Objectives: Patients with seizures constitute $1 \%-2 \%$ of all emergency department (ED) admissions. The purpose of this study was to compare demographic and clinical characteristics and short-term mortality in patients with unprovoked first and recurrent seizures, admitted to the ED. Methods: This prospectively planned study was conducted in a university hospital ED between January and December, 2015, and included patients with unprovoked seizures. Demographic characteristics, neurological examination findings, etiological risk factors, seizure type, and frequency, electroencephalography and neuroimaging findings, hospitalization rate, duration of hospitalization, short-term mortality, and medical and family history data were recorded.
\end{abstract}

Results: A total of 125 patients ( $62.4 \%$ male, $n=78$ ) with a mean age of $40.10 \pm 17.09$ years (range, 18-86) were included in the study. The level of patients presenting due to first lifetime seizure was $23.2 \%$. The short-term mortality rate in patients with status epilepticus (SE) was $7.69 \%$. The most common finding at electroencephalography was interictal epileptic discharges.

Conclusion: A careful evaluation of cases presenting due to first lifetime seizure and initiation of antiepileptic drug therapy in the early period will significantly reduce the risk of seizure recurrence and also prevent complications, such as SE that can even result in death.

Keywords: Electroencephalography; emergency; first-seizure; mortality; status epilepticus; unprovoked seizure.

Özet

Amaç: Acil servis başvurularının \%1-2'si nöbet geçirme nedeniyle başvuran hastalardan oluşmaktadır. Bu çalışmada acil servise ilk nöbet ya da rekürren nöbet nedeniyle başvuran hastalarda klinik ve demografik özelliklerin karşılaştırılması ve bu hastalarda kısa dönem mortalitenin belirlenmesi amaçlanmıştır.

Gereç ve Yöntem: Illeriye yönelik olarak planlanan bu çalışmaya bir üniversite hastanesinin acil servisine Ocak 2015-Aralık 2015 arasında nonprovoke nöbet nedeniyle başvuran hastalar alınmıştır. Başvuru nöbet sıklığına göre hastalar tek nöbet, sık nöbet ve status epileptikus olarak üç gruba ayrıldı. Demografik özellikler, özgeçmiş ve soygeçmiş özellikleri, nörolojik muayene, epilepsi risk faktörleri, nöbet tipi ve sıklığı, elektroensefalografi, nörogörüntüleme, hastaneye yatış oranı, ortalama yatış süresi ve kısa dönem mortalite veri formuna kaydedildi.

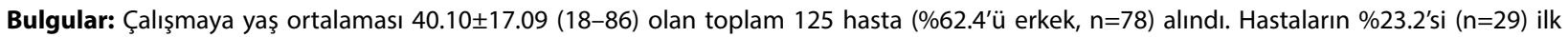
nöbet nedeniyle başvurdu. Status epileptikus olgularında kısa dönem mortalite oranı \%7.69 idi. En sık elektroensefalografi bulgusu interiktal epileptik boşalımlar olarak dikkati çekti.

Sonuç: Acil servise nöbet nedeniyle başvuran hastalarda doğru ve hızlı tanı konulmalı, gerekirse yatış yapılarak nöbet gözlemlenmeye çalışılmalıdır. İlk nöbet ile başvuran hastalarda dikkatli bir değerlendirme ve erken dönemde antiepileptik tedavi başlanması hem nöbet tekrarını hem de status epileptikus ve onun yıkıcı bir komplikasyonu olan mortalite riskini azaltacaktır.

Anahtar sözcükler: Elektroensefalografi; acil servis; ilk nöbet; mortalite non-provoke nöbet; status epileptikus.

(C) 2018 Türk Epilepsi ile Savaş Derneği

(C) 2018 Turkish Epilepsy Society
Submitted (Geliş): 18.04.2018

Accepted (Kabul) : 04.09.2018

Correspondence (Illetişim): Turgay DEMIR, M.D.

e-mail (e-posta): drtdemir@gmail.com 


\section{Introduction}

Approximately $8 \%-10 \%$ of the population undergoes at least one seizure during the afebrile period. ${ }^{[1]}$ Patients with seizures are generally first evaluated in the emergency department (ED). Approximately $1 \%-2 \%$ of ED patients are reported to have epileptic seizures. ${ }^{[2]}$

Not all attacks described as seizures by patients or relatives are epileptic seizures. They can also be provoked seizures, syncope, or non-epileptic psychogenic attacks. Provoked seizures are acute transient seizures occurring in the central nervous system for metabolic, toxic, structural, infectious, or inflammatory reasons, and therefore with a temporal relation between them (generally the first 7 days). ${ }^{[3]}$ Provoked seizures recur very rarely and do not generally require antiepileptic drug (AED) therapy. ${ }^{[4,5]}$

In addition, some patients may experience a first lifetime seizure. The incidence of seizure recurrence in first-seizure patients is reported to range between $3 \%$ and $10 \%$ in acute symptomatic or provoked seizures, and between $23 \%$ and $71 \%$ in unprovoked seizures. ${ }^{[6-8]}$ Seizure symptomatology and electroencephalography (EEG) and neuroimaging findings must not be overlooked in terms of early and accurate diagnosis and early initiation of AEI therapy, especially in patients presenting to the ED with first-seizure. However, EEG is not always available in the early period of the disease, especially in the ED. It is frequently performed in outpatient clinics in the following days, although some patients are not referred to the outpatient clinic, so epilepsy may be either diagnosed late or not at all.

Status epilepticus (SE) is defined in the 2015 International League Against Epilepsy guideline as recurring seizures exceeding $5 \mathrm{~min}$ (generalized convulsive SE) or $10 \mathrm{~min}$ (focal $\mathrm{SE}$ ) in duration or not permitting a return to baseline status. ${ }^{[9]} \mathrm{SE}$ is the second most common neurological emergency, and it has high mortality and morbidity risk. ${ }^{[10]}$ Seven percent of these patients are referred to the ED with SE. ${ }^{[1]}$ The management of SE in the ED is particularly important in terms of clinical course and prognosis. The mortality rate in the first month after SE was reported to be $31.7 \%$ by Hocker et al., ${ }^{[12]} 21 \%$ by Classen, ${ }^{[13]} 16.9 \%$ by Moghaddasi et al. ${ }^{\left[{ }^{[10]}\right.}$ and $3.45 \%$ by Koubeissi. ${ }^{[14]}$

The purpose of this prospective study was to determine demographic and clinical features, electroencephalo- graphic and neuroimaging findings and mortality in the acute period of patients admitted to the ED with seizure, and to compare the first unprovoked seizures and recurrent seizures.

\section{Materials and Methods}

This single-center, prospective observational study was conducted between January and December, 2015, in a university hospital. Unprovoked and provoked seizures, syncope, and non-epileptic psychogenic attacks were diagnosed by a neurologist specializing in epilepsy. Informed consent forms were obtained from patients or their relatives. The study was approved by the University Ethics Committee.

\section{Participants}

Consecutive patients aged 18 years or older who provided informed consent forms (either personally or from firstdegree relatives) were included in the study. Patients with recurrent $E D$ admissions were included only once in the study, represented by the first presentation. Since seizures in the first 7 days associated with alcohol dependence, medication discontinuation, metabolic disease (such as hyponatremia, hypocalcemia, uremia, and advance stage live disease), and acute cerebral lesions (such as acute stroke) were regarded as provoked seizures, these were not included in the study. Additionally, patients diagnosed with syncope or non-epileptic psychogenic attack were excluded from the study.

Following emergency measures and clinical stabilization, patients and their relatives were asked about the history of seizures. Patients were also divided into three groups, depending on the frequency of seizures on admission: a single-seizure group, a frequent seizure group, and a SE group. Patients who had two or more seizures on the admission day, but were not diagnosed as SE, were considered to constitute the frequent seizure group. Demographics, etiological risk factors, seizure type and frequency, hospitalization, AEDs, and medical and family history data were recorded. Etiological risk factors investigated included head trauma, febrile convulsions, interventional or difficult birth, a family history of epilepsy, parental consanguinity, central nervous system infection, cerebrovascular disease, and tumor. In addition, cases presenting to the ED due to first lifetime seizure and patients with a previous history of seizures were identified. Patients with first-seizure were referred to 
the epilepsy outpatient clinic and evaluated for appropriate antiepileptic therapy on the basis of a detailed seizure history, neurological examination, and laboratory findings. Focal and generalized seizures were classified depending on the seizure type.

\section{Examinations}

\section{EEG}

All patients underwent EEG within the first $24 \mathrm{~h}$ after admission. This was performed using the international 10-20 system with a 16-channel, 21-electrode digital EEG device. Thirty-minute routine EEG recordings, including hyperventilation and photic stimulation, were performed by certified EEG technicians. Cases were classified as normal, interictal epileptic discharges, and focal or generalized slowing, depending on the EEG traces.

\section{Neuroimaging}

Magnetic resonance imaging (MRI) of the brain was performed in all patients in the first 7 days after admission. MRI findings were evaluated by a radiologist blinded to the patient's clinical status. Patients were divided into two groups, based on the neuroimaging results: Group 1, normal; Group 2, abnormal.

\section{Statistical analysis}

A statistical analysis was performed using the Statistical Package for the Social Sciences version 16.0 software (SSPS Inc., Chicago, IL, USA). Normal distribution of data was assessed using the Kolmogorov-Smirnov test. Parametric tests were applied in the analysis of normally distributed data, and non-parametric tests were applied for non-normal distribution. Descriptive statistics (number-percentage, mean, standard deviation, and minimum-maximum) were used in the evaluation of continuous and censored variables. The chi-squared and Fisher's exact tests were used to compare categorical variables between groups. Statistical significance was set at $p<0.05$.

\section{Results}

A total of 253 consecutive patients were evaluated in the ED due to seizure. One hundred and three patients diagnosed with provoked seizure, non-epileptic psychogenic attack, or syncope, and 25 cases assessed as non-provoked seizures, but in which investigations could not be completed, were excluded from the study. One hundred and twenty-five patients diagnosed with unprovoked seizures, $62.4 \%$ male $(n=78)$, with a mean age of $40.10 \pm 17.09$ years (range, 1786), were finally included in the study. The mean age at the onset of seizure was $30.86 \pm 22.54$ years (range, 1-85) (Table 1). In terms of seizure frequency on admission, $49.6 \%(n=50)$ of patients were in the single-seizure group, $40 \%(n=62)$ in the frequent seizure group, and $10.4 \%(n=13)$ in the SE group. In this study, non-convulsive SE was diagnosed with EEG findings in two cases of consciousness impairment after a generalized tonic-clonic seizure. A previous history of seizures before presentation to the ED was present in $76.8 \%$ ( $n=96)$ of patients, while $23.2 \%(n=29)$ of cases presented to the ED due to first lifetime seizure. Fifty-four percent $(n=27)$ of patients in the single-seizure group described at least one previous unprovoked seizure, while $46 \%(n=23)$ presented with the first lifetime seizure. In addition, 23.1\% $(n=3)$ of the patients in the SE group presented due to firstseizure and described no previous history of seizures.

Head injury (15.2\%), febrile convulsions (13.6\%), and parental consanguinity (14.4\%) were the three most common etiological risk factors for epilepsy. In terms of prevalence of presentation seizures, a history of febrile convulsion was more common in the frequent seizure and status group compared to the single-seizure group $(\mathrm{p}=0.05)$ (Table 2 ).

Partial and generalized seizures were similar in frequency ( $44 \%$ vs. $56 \%$ ) compared to referral seizure types. Generalized seizures were more common than partial seizures in all three groups, although there was no statistically sig-

Table 1. Demographic characteristics

\begin{tabular}{lccccc}
\hline & Single seizure & Frequent seizure & Status epilepticus & Total & $\mathrm{p}$ \\
\hline $\mathrm{n}(\%)$ & $50(40)$ & $62(49.6)$ & $13(10.4)$ & 125 & \\
Sex, $\mathrm{n}(\%)$ & & & & & \\
$\quad$ Female & $22(44)$ & $22(35.5)$ & $3(23.1)$ & $47(37.6)$ & 0.34 \\
$\quad$ Male & $28(56)$ & $40(64.5)$ & $10(76.9)$ & $78(62.4)$ & \\
Mean age & $44.66 \pm 18.95$ & $34.77 \pm 13.31$ & $47.92 \pm 18.73$ & $40.1 \pm 17.09$ & 0.02 \\
Mean age at onset of seizure & $37.98 \pm 24.03$ & $22.9 \pm 17.49$ & $41.46 \pm 26.01$ & $30.86 \pm 22.54$ & $<0.01$ \\
\hline
\end{tabular}


Table 2. Comparison of clinical features in terms of seizure frequency on admission

\begin{tabular}{|c|c|c|c|c|c|}
\hline & $\begin{array}{l}\text { Single } \\
\text { seizure }\end{array}$ & $\begin{array}{l}\text { Frequent } \\
\text { seizure }\end{array}$ & $\begin{array}{c}\text { Status } \\
\text { epilepticus }\end{array}$ & Total & $\mathrm{p}$ \\
\hline \multicolumn{6}{|l|}{ Risk factors for epilepsy n (\%) } \\
\hline Head trauma & $1(7.7)$ & $12(19.4)$ & $6(46.2)$ & $19(15.2)$ & NS \\
\hline Febril convulsion & $1(7.7)$ & $13(21)$ & $3(23.1)$ & $17(13.6)$ & 0.05 \\
\hline Brain tumor & $6(12)$ & $5(8.1)$ & $3(23.1)$ & $14(11.2)$ & NS \\
\hline Stroke & $3(6)$ & $5(8.1)$ & $2(15.4)$ & $10(8)$ & NS \\
\hline Difficult delivery & $2(4)$ & $8(12.9)$ & $1(7.7)$ & $11(8.8)$ & NS \\
\hline CNS infection & $6(12)$ & $6(9.7)$ & $2(15.4)$ & $14(11.2)$ & NS \\
\hline Family history of epilepsy & $5(10)$ & $7(11.3)$ & 0 & $12(9.6)$ & NS \\
\hline Parental consanguinity & $9(18)$ & $9(14.5)$ & 0 & $18(14.4$ & NS \\
\hline \multicolumn{6}{|l|}{ Seizure type } \\
\hline Focal & $20(40)$ & $29(46.8)$ & $6(46.2)$ & $55(44)$ & \\
\hline Generalized & $30(60)$ & $33(53.2)$ & $7(53.8)$ & $70(56)$ & NS \\
\hline \multicolumn{6}{|l|}{ EEG (\%) } \\
\hline Normal & $16(32)$ & $15(22.6)$ & $1(7.6)$ & $32(25.6)$ & \\
\hline Interictal epileptic discharges & $25(50)$ & $34(54.8)$ & $6(46.2)$ & $65(52)$ & \\
\hline Focal slowing & $3(6)$ & $5(8)$ & 0 & $28(6.4)$ & \\
\hline Generalized slowing & $6(12)$ & $8(13)$ & $6(46.2)$ & $20(16)$ & 0.01 \\
\hline \multicolumn{6}{|l|}{ Neuroimaging (MRI/CT) n (\%) } \\
\hline Normal & $20(40)$ & $27(43.5)$ & $3(23.1)$ & $50(39.2)$ & \\
\hline Abnormal & $30(60)$ & $35(56.5)$ & $10(76.9)$ & $75(60.8)$ & NS \\
\hline Cerebral infarction, ischemic changes, gliosis & $13(26)$ & $16(25.8)$ & $5(38.4)$ & $34(27.6)$ & \\
\hline Cerebral-cerebellar atrophy & $1(2)$ & $3(4.8)$ & $2(15.3)$ & $6(4.9)$ & \\
\hline Tissue defect, postoperative changes, leukomalasia & $7(14)$ & $10(16.1)$ & $3(23)$ & $20(16.2)$ & \\
\hline Intracranial tumor, arachnoid cyst & $6(12)$ & $4(6.4)$ & 0 & $10(8.1)$ & \\
\hline Developmental anomaly & $3(6)$ & $2(3.2)$ & 0 & $5(4)$ & \\
\hline \multicolumn{6}{|l|}{ AED treatment status } \\
\hline Patients declared regular treatment & $22(44)$ & $49(79)$ & $7(53.8)$ & $78(62.4)$ & \\
\hline Untreated or irregular treatment & $28(56)$ & $13(21)$ & $6(46.2)$ & $47(37.6)$ & 0.001 \\
\hline
\end{tabular}

CNS: Central nervous system; CT: Computerized tomography; EEG: Electroencephalography; AED: Antiepileptic drug; MRI: Magnetic resonance imagination; NS: Not significant.

nificant difference between the groups in terms of seizure types ( $p>0.05)$. Interictal epileptic discharges was the most common (52\%) EEG finding among all groups. Interictal epileptiform discharges were not related to MRI findings. Generalized seizures were seen in the majority of patients with interictal epileptiform discharges. Cerebral MRI results were compared between the groups according to the seizure frequency on admission, and $60.8 \%$ of patients had abnormal findings at MRI. The EEG findings in the majority of patients with abnormal MR findings were also abnormal, although there was no correlation between MRI findings and seizure types. There was no difference between the groups in terms of frequency of seizures on admission at neuroimaging $(p=0.39)$. In terms of treatment status, $46.2 \%(n=6)$ of the SE group, $21 \%(n=13)$ of the frequent seizure group and $56 \%(n=28)$ of the single-seizure group received no or irregular treatment. Since $79 \%(n=49)$ of the patients in the frequent seizure group were referred due to frequent seizures while declared regular treatment, this suggests that treatments should be further reviewed for effective AED therapy. The incidence of untreated patients or non-compliant patients was greater in the single-seizure or status group compared to the frequent seizure group $(\mathrm{p}=0.001)$ (Table 2).

Women constituted $62.1 \%(n=16)$ of the patients presenting with first lifetime seizure and $31.3 \%(n=31)$ of the recurrent seizure group ( $p=0.005)$. The mean age and age at the onset of seizure were higher in the first lifetime seizure group compared to the recurrent seizure group $(p=0.006$ 
Table 3. Comparison of clinical and demographic features in patients presenting with first-seizure and recurrent seizures

\begin{tabular}{|c|c|c|c|}
\hline & Recurrent seizure & First seizure & $\mathrm{p}$ \\
\hline \multicolumn{4}{|l|}{ Sex, n (\%) } \\
\hline Male & $29(30.2)$ & $18(62.1)$ & \\
\hline Female & $67(69.8)$ & $11(37.9)$ & 0.005 \\
\hline Mean age & $37.52 \pm 15.33$ & $49.88 \pm 20.04$ & 0.006 \\
\hline Mean age at onset of seizure & $26.39 \pm 20.59$ & $49.88 \pm 20.04$ & $<0.001$ \\
\hline \multicolumn{4}{|l|}{ Risk factors for epilepsy, n (\%) } \\
\hline Head trauma & $17(17.2)$ & $2(7.7)$ & NS \\
\hline Febrile convulsion & $16(16.2)$ & $1(3.8)$ & 0.06 \\
\hline Brain tumor & $11(11.1)$ & $3(11.5)$ & NS \\
\hline Stroke & $8(8.1)$ & $2(7.7)$ & NS \\
\hline Difficult delivery & $11(11.1)$ & 0 & 0.07 \\
\hline CNS infection & $10(10.1)$ & $4(15.4)$ & NS \\
\hline Family history of epilepsy & $11(11.1)$ & $1(3.8)$ & NS \\
\hline Parental consanguinity & $13(13.1)$ & $5(19.2)$ & NS \\
\hline \multicolumn{4}{|l|}{ Neurological exam } \\
\hline Normal & $63(65.3)$ & $17(59.7)$ & \\
\hline Abnormal & $33(34.7)$ & $12(41.3)$ & NS \\
\hline \multicolumn{4}{|l|}{ Seizure type, n (\%) } \\
\hline Focal & $43(44.7)$ & $12(41.3)$ & \\
\hline Generalized & $53(55.3)$ & $17(59.7)$ & NS \\
\hline \multicolumn{4}{|l|}{ Electoencephalography, n (\%) } \\
\hline Normal & $24(25)$ & $8(27.7)$ & \\
\hline Interictal epileptic discharges & $53(55.2)$ & $12(41.3)$ & \\
\hline Focal slowing & $5(4.7)$ & $4(13.7)$ & \\
\hline Generalized slowing & $14(15.1)$ & $5(17.3)$ & NS \\
\hline \multicolumn{4}{|l|}{ Neuroimaging, $\mathrm{n}(\%)$} \\
\hline Normal & $39(40.6)$ & $11(37.9)$ & \\
\hline Abnormal & $57(59.4)$ & $18(62.1)$ & NS \\
\hline Cerebral infarction, ischemic changes, gliosis & $28(29.1)$ & $7(24.1)$ & \\
\hline Cerebral-cerebellar atrophy & $4(4.2)$ & $3(10.3)$ & \\
\hline Tissue defect, postoperative changes, leukomalasia & $18(18.7)$ & $3(10.3)$ & \\
\hline Intracranial tumor, arachnoid cyst & $5(5.2)$ & $4(13.8)$ & \\
\hline Developmental anomaly & $2(2.1)$ & $1(3.7)$ & \\
\hline
\end{tabular}

NS: Not significant.

and $p<0.001$, respectively). When the two groups were evaluated in terms of epilepsy risk factors, histories of febrile convulsions, and of difficult birth were higher in the recurrent seizure group ( $p=0.06$ and $p=0.07$, respectively). No statistically significant difference was observed between the recurrent- and first-seizure groups in terms of seizure type, EEG, or neuroimaging findings ( $p>0.05$ ) (Table 3).

In this study, $10.4 \%$ of patients had SE, one of whom died. The mortality rate among our SE patients was $7.69 \%$. Ischemic stroke and subsequent pneumonic sepsis were regarded as the cause of death in a 76-year-old patient.

\section{Discussion}

The number of patients admitted to the ED with seizure symptoms is very high. Seizures account for $1 \%$ of all ED admissions in the United States. ${ }^{[2]}$ However, the number of cases evaluated as unprovoked seizures is much lower. Approximately, $6 \%$ of these patients are $\mathrm{SE}$, whereas $24 \%$ of them are first seizures. ${ }^{[15]}$ In our study, $10.3 \%$ of the patients had $\mathrm{SE}$, and $23.2 \%$ had the first-seizure, in agreement with the previous literature. It was also noteworthy that the three patients presenting with first-seizure presented with a manifestation of SE. 
Epilepsy risk factors vary depending on age. Head trauma, central nervous system infections, and brain tumors are antagonistic as risk factors for all age groups. ${ }^{[16]}$ Cerebrovascular diseases are the most common risk factor in patients over $60 .{ }^{[17]}$ Annegers et al. ${ }^{[18]}$ reported that the most common seizure etiologies were head trauma (16\%), cerebrovascular diseases (16\%), and infections (15\%). The most common risk factors for epilepsy identified in our study were head trauma, febrile convulsion history, and parental consanguinity.

Paliwal et al. ${ }^{[19]}$ reported $29.4 \%$ abnormal EEG in 136 firstseizure patients, and focal epileptiform abnormality is the most seen abnormal EEG finding. They reported abnormal neuroimaging in $14.7 \%$ of patients. In our study, abnormal EEG was found in $72.3 \%$ of the first-seizure patients, and the most common abnormal EEG finding is interictal epileptic discharges. We found abnormal neuroimaging in $62.1 \%$ of first-seizure patients. Paliwal et al. used MRI as neuroimaging in $33.6 \%$ of patients, although we used MRI in all of our patients. This can be explained by the fact that abnormal MRI findings are more common in our patients. The presence of abnormal EEG and neuroimaging in patients undergoing first unprovoked seizures are important factors indicating a high risk of recurrence. ${ }^{[8]}$

Some studies have reported rates of epileptiform activity changes between $20 \%$ and $50 \%$ at EEG performed within the first 24-48 $\mathrm{h}$ among ED patients with first-seizure symptoms. ${ }^{[5,20-22]}$ In this study, the presence of interictal epileptic discharges at EEG was $42.3 \%$ in patients with first seizures. In first-seizure patients, early EEG is more likely to be epileptic than late EEG (50\% vs. $34 \%) .{ }^{[20]}$ In our study, EEG was performed in the early period. Successful seizure control is achieved with initial monotherapy in $47 \%$ of patients referred for first epileptic seizures and diagnosed with epilepsy. ${ }^{[23]}$ Wyman et al. ${ }^{[24]}$ reported that $24 \%(n=17)$ of 71 patients presenting with first-seizure were started on AEDs and that epilepsy was diagnosed in $88 \%$ of patients receiving AED therapy based on EEG findings. Abnormal but nonepileptic EEG findings were detected in $25 \%$ of patients. In our study, EEG was normal in $26.9 \%$ of first-seizure patients, while in $30.8 \%$ of cases, EEG was not epileptic, but focal, or subcortical slowing was detected.

It has been reported that the risk of recurrence is high in the first-seizure patients with EEG abnormalities, a prior brain lesion, a significant brain imaging abnormality, and a nocturnal seizure. ${ }^{[3]}$ The 1-year risk of seizure recurrence has been reported to decrease between $35 \%$ and $57 \%$ with AED therapy in patients identified as undergoing non-provoked seizures, while the 3-year risk of seizure recurrence decreased between $50 \%$ and $72 \% .{ }^{[25]}$ The most important issue to be decided in the ED in patients with seizures is whether or not the subject is provoked for seizure. In addition, whether the patient is undergoing a first episode, and whether this first episode is unprovoked, require careful neurological evaluation in terms of epilepsy. In our study, AED therapy was initiated in $55.1 \%$ of the first-seizure group. Unfortunately, our patients with first-seizure did not have long-term follow-ups.

The risk of life-long acute symptomatic seizures has been reported at $5.0 \%$ in men and $2.7 \%$ in women in the United States, and it is 1.85 -fold higher in men than women. ${ }^{[18]}$ However, the risk of epileptic seizures is only slightly higher in men than in women. ${ }^{[26]}$ In this study, the male-to-female ratio was 1.65 in patients presenting to the ED due to an epileptic seizure.

First 30 -day mortality rates ranging between $2.7 \%$ and $32 \%$ have been reported in SE cases. ${ }^{[27]}$ A mortality rate for refractory SE is three times greater than for non-refractory SE. ${ }^{[28]}$ In this study, the mortality rate was $7.69 \%$ among SE patients, and the patient who died was diagnosed with refractory SE.

Our study limitations were the number of patients and the lack of long-term follow-ups of first-seizure patients.

\section{Conclusions}

A careful and detailed evaluation of patients with first seizures is important for diagnosis of epilepsy. A detailed history of seizures, completion of examinations with hospitalization if necessary, observation of the seizure for a sufficient length of time for diagnosis in this patient group, and immediate initiation of AED therapy in subjects diagnosed with epilepsy are most important in terms of the course and prognosis of the disease. The next presentation by a patient with inadequate treatment or not receiving AED therapy may be due to frequent seizures or $\mathrm{SE}$, sometimes resulting in long-term hospitalization, and even worse, in mortality and morbidity.

\section{Ethics Committee Approval}

Ethics committee approved.

\section{Peer-review}

Externally peer-reviewed. 


\section{Conflict of interest}

The authors declare that they have no conflict of interest.

\section{Authorship Contributions}

Concept: T.D., K.A., H.B.; Design: T.D., K.A.; Supervision: H.B., Z.K.; Materials: T.D., G.K.Ş.; Data collection \&/or processing: T.D., G.K.Ş.; Analysis and/or interpretation: T.D., K.A., G.K.Ş.; Literature search:T.D., K.A.; Writing:T.D., K.A.; Critical review: H.B., Z.K.

\section{References}

1. Hauser WA, Rich SS, Annegers JF, Anderson VE. Seizure recurrence after a 1st unprovoked seizure: an extended follow-up. Neurology 1990;40(8):1163-70. [CrossRef]

2. Pallin DJ, Goldstein JN, Moussally JS, Pelletier AJ, Green AR, Camargo CA Jr. Seizure visits in US emergency departments: epidemiology and potential disparities in care. Int J Emerg Med 2008;1(2):97-105. [CrossRef]

3. Beghi E, Carpio A, Forsgren L, Hesdorffer DC, Malmgren K, Sander JW, et al. Recommendation for a definition of acute symptomatic seizure. Epilepsia 2010;51(4):671-5. [CrossRef]

4. Hesdorffer DC, Benn EK, Cascino GD, Hauser WA. Is a first acute symptomatic seizure epilepsy? Mortality and risk for recurrent seizure. Epilepsia 2009;50(5):1102-8. [CrossRef]

5. Krumholz A, Wiebe S, Gronseth GS, Gloss DS, Sanchez AM, Kabir AA, et al. Evidence-based guideline: Management of an unprovoked first seizure in adults: Report of the Guideline Development Subcommittee of the American Academy of Neurology and the American Epilepsy Society. Neurology 2015;84(16):1705-13. [CrossRef]

6. Berg AT, Shinnar S. The risk of seizure recurrence following a first unprovoked seizure: a quantitave review. Neurology 1991;41(7):965-72. [CrossRef]

7. Elwes RD, Chesterman P, Reynolds EH. Prognosis after a first untreated tonic-clonic seizure. Lancet 1985;2(8458):752-3.

8. Kim LG, Johnson TL, Marson AG, Chadwick DW; MRC MESS Study group. Prediction of risk of seizure recurrence after a single seizure and early epilepsy: further results from the MESS trial. Lancet Neurol 2006;5(4):317-22. [CrossRef]

9. Trinka E, Cock H, Hesdorffer D, Rossetti AO, Scheffer IE, Shinnar $S$, et al. A definition and classification of status epilepticus-Report of the ILAE Task Force on Classification of Status Epilepticus. Epilepsia 2015;56(10):1515-23. [CrossRef]

10. Moghaddasi M, Joodat R, Ataei E. Evaluation of Short-term Mortality of Status Epilepticus and Its Risk Factors. J of Epilepsy Res 2015;5(1):13-16. [CrossRef]

11. Sloan E, Silva J, Rosenberg M. Outcome in adult seizure patients treated in the emergency setting. Ann Emerg Med 1999;34(4):S101. [CrossRef]

12. Hocker SE, Britton JW, Mandrekar JN, Wijdicks EF, Rabinstein AA. Predictors of outcome in refractory status epilepticus. JAMA Neurol 2013;70(1):72-7. [CrossRef]

13. Claassen J, Lokin JK, Fitzsimmons BF, Mendelsohn FA, Mayer SA. Predictors of functional disability and mortality after status epilepticus. Neurology 2002;58(1):139-42. [CrossRef]

14. Koubeissi M, Alshekhlee A. In-hospital mortality of generalized convulsive status epilepticus: a large US sample. Neurology 2007;69(9):886-93. [CrossRef]

15. Huff JS, Morris DL, Kothari RU, Gibbs MA; Emergency Medicine Seizure Study Group. Emergency department management of patients with seizures: a multicenter study. Acad Emerg Med 2001;8(6):622-8. [CrossRef]

16. Duncan JS, Sander JW, Sisodiya SM, Walker MC. Adult Epilepsy. Lancet 2006;367(9516):1087-100. [CrossRef]

17. Granger N, Convers P, Beauchet O, Imler D, Viallon A, Laurent $B$, et al. First epileptic seizure in the elderly: electroclinical and etiological data in 341 patients. [Article in French]. Rev Neurol (Paris) 2002;158(11):1088-95.

18. Annegers JF, Hauser WA, Lee JR, Rocca WA. Incidence of acute symptomatic seizures in Rochester, Minnesota, 1935-1984. Epilepsia 1995;36(4):327-33. [CrossRef]

19. Paliwal P, Wakerley BJ, Yeo LL, Ali KM, Ibrahim I, Wilder-Smith $\mathrm{E}$, et al. Early electroencephalography in patients with Emergency Room diagnoses of suspected new-onset seizures: Diagnostic yield and impact on clinical decision-making. Seizure 2015;31:22-6. [CrossRef]

20. King MA, Newton MR, Jackson GD, Fitt GJ, Mitchell LA, Silvapulle $M J$, et al. Epileptology of the first seizure presentation: a clinical, electroencephalographic, and magnetic resonance imaging study of 300 consecutive patients. Lancet 1998;352(9133):1007-11. [CrossRef]

21. Pohlmann-Eden B, Newton M. First seizure: EEG and neuroimaging following an epileptic seizure. Epilepsia 2008;49(Suppl 1):19-25. [CrossRef]

22. Sierra-Marcos A, Toledo M, Quintana M, Edo MC, Centeno M, Santamarina $E$, et al. Diagnosis of epileptic syndrome after a new onset seizure and its correlation at long-term follow-up: longitudinal study of 131 patients from the emergencyroom. Epilepsy Res 2011;97(1-2):30-6. [CrossRef]

23. Kwan P, Brodie MJ. Early identification of refractory epilepsy. $\mathrm{N}$ Engl J Med 2000;342(5):314-9. [CrossRef]

24. Wyman AJ, Mayes BN, Hernandez-Nino J, Rozario N, Beverly SK, Asimos AW. The First-Time Seizure Emergency Department Electroencephalogram Study. Ann Emerg Med 2017;69(2):184-91.

25. Marson A, Jacoby A, Johnson A, Kim L, Gamble C, Chadwick D, et al. Immediate versus deferred antiepileptic drug treatment for early epilepsy and single seizures: a randomised controlled trial. Lancet 2005;365(9476):2007-13. [CrossRef]

26. Kotsopoulos IA, van Merode T, Kessels FG, de Krom MC, Knottnerus JA. Systematic review and meta-analysis of incidence studies of epilepsy and unprovoked seizures. Epilepsia 2002:43(11):1402-9. [CrossRef]

27. Neligan A, Shorvon SD. Prognostic factors, morbidity and mortality in tonic-clonic status epilepticus: a review. Epilepsy Res 2011;93(1):1-10. [CrossRef]

28. Rossetti AO, Lowenstein $\mathrm{DH}$. Management of refractory status epilepticus in adults: still more questions than answers. Lancet Neurol 2011;10(10):922-30. [CrossRef] 